BIO-CONS, Jurnal Biologi \& Konservasi

Volume 3 No. 2, Desember 2021

p-ISSN : 2620-3510, e-ISSN: 2620-3529

\title{
PEMANFAATAN DAUN Psidium guajava SEBAGAI BAHAN ALTERNATIF DALAM MENJAGA KUALITAS TELUR SELAMA PROSES PENYIMPANAN
}

\section{UTILIZATION OF Psidium guajava LEAVES AS ALTERNATIVE INGREDIENTS IN MAINTAINING EGGS QUALITY DURING STORAGE PROCESS}

\author{
Septarini Dian Anitasari*), Dwi Nur Rikhma Sari, Yeni Dwi Rofikah \\ *) Corresponding Author \\ ${ }^{1,2,3}$ Program Studi Biologi, Fakultas Sains Dan Teknologi Universitas PGRI Argopuro Jember \\ Email: septarinidian867@gmail.com
}

\begin{abstract}
ABSTRAK
Penelitian ini dilakukan untuk mengetahui potensi daun jambu biji (Psidium guajava) sebagai bahan alternatif dalam proses penyimpanan telur. Metode yang digunakan yaitu dengan cara observasi, dan eksperimen (percobaan) menggunakan uji RAL yang diulang sebanyak 3 kali. Adapun faktor penelitian ini yaitu menggunakan ekstrak daun jambu biji sebesar $10 \%$ dengan perlakuan renadam selama 1,12 , dan 24 jam. Pengamatan pada penelitian ini dilakukan pada minggu ke-1, minggu ke-2 dan minggu ke-4. Hasil penelitian untuk nilai haugh unit pada minggu ke-1 yaitu nilai haugh unit dengan rata - rata 82,79 dengan kualitas AA. Pada minggu ke-2 dengan lama perendaman 1 dan 12 jam nilai haugh unitnya 77,39 dengan kualitas AA dan pada perendaman 24 jam nilai haugh unitnya 71,81 dengan kualitas B. Sedangkan pada minggu ke-4 pada perendaman 1 dan 12 jam hanya memiliki kualitas A dengan nilai haugh unit 65,56 sedangkan pada perendaman 24 jam memiliki kualitas B.
\end{abstract}

Kata kunci: Psidium guajava, Kualitas Telur Ayam, Haugh Unit.

\begin{abstract}
This research was conducted to determine the potential of guava leaves (Psidium guajava) as an alternative material in the egg storage process. The method used by means of observation, and experiments (experiments) using the RAL test which was repeated 3 times. The factors of this research were using guava leaf extract by $10 \%$ with soaking treatment for 1 , 12, and 24 hours. Observations in this study were carried out at week 1, week 2 and week 4. The results of the study for the value of the haugh unit in week 1, namely the value of the haugh unit with an average of 82.79 with AA quality. In the 2nd week with 1 and 12 hours of immersion the haugh unit value was 77.39 with AA quality and at 24 hours immersion the haugh unit value was 71.81 with B quality. While in the 4th week at 1 and 12 hours immersion only had A quality with haugh unit value of 65.56 while at 24 hours immersion, it has a B quality.
\end{abstract}

Keywords: Psidium guajava, Chicken Egg Quality, Haugh Unit. 


\section{PENDAHULUAN}

Telur adalah salah satu produk hewani yang memiliki kandungan protein, vitamin dan lemak yang sangat dibutuhkan bagi metabolisme sel dalam proses pertumbuhan dam perkembangan makhluk hidup. Selain itu, pada satu butir telur mentah juga mengandung kalori sebesar 74 yang terdiri atas 0,38 gram karohidrat, 1,55 gram lemak jenuh, 6,29 gram protein dan 4,97 gram lemak. Berdasarkan data tersebut dapat kita ketahui bahwa telur memiliki banyak kandungan gizi yang relatif tinggi (Idayanti $d k k ., 2009)$.

Meski memiliki kandungan yang tinggi, telur mentah memiliki sifat yang mudah rusak, pecah dan mengalami penurunan kualitas yang disebabkan oleh reaksi kimia dalam telur maupun kerusakan fisik (Muchtadi dan Ayustaningwarno, 2010), sehingga lama waktu dalam penyimpanan telur sangat menentukan kualitasnya, dimana semakin lama penyimpanannya maka kualitas telur tersebut semakin menurun (Haryoto, 2010). Telur ayam yang telah disimpan dalam suhu ruang memiliki kemampuan bertahan selama 14 hari dan jika dibiarkan teruss-menerus maka telur akan mengalami berbagai perubahan yang mengarah pada sifat kerusakannya (Cornelia, 2014).

Beberapa penelitian yang telah dilakukan untuk mengatasi problem dalam menjaga kualitas telur, salah satunya dengan cara fisik dengan pemanasan maupun dengan perendaman menggunakan air yang telah dilarutkan dengan kapur yang menunjukkan hasil signifikan dalam menajga kualitas telur (Djaelani, 2016). Penelitian yang telah dilakukan selama ini memiliki kekurangan salah satunya memerlukan waktu dan perlakuan yang lebih panjang, sehingga diperlukan alternatif lain yang lebih sederhana dan mudah dilakukan.

Salah satu metode yang dapat dilakukan untuk menjaga kualitas telur selama proses penyimpanan yaitu dengan merendamnya menggunakan ekstra tanaman yang aman untuk dikonsumsi, salah satunya dengan menggunakan ekstrak jambu biji (Psidium guajava).

Psidium guajava diduga memiliki kandungan senyawa flavonoid berupa tanin (Thomas, 1989), minyak atsiri sebesar 0,4 \%, minyak lemak 6\% dan senyawa psidtanin sebesar 9\% (Lestari et al., 2013). Kandungan tanin pada Psidium guajava berupa psidtanin yang memiliki kemampuan mengendapkan senyawa alkaloid dan mampu mengendapkan protein pada telur. Selain itu, kandungan tanin juga memiliki sifat sebagai antibakteri dan absorbent.

Berdasarkan latar belakang tersebut, ekstrak daun Psidium guajava diharapkan dapat digunakan sebagai bahan perendaman alternatif yang mudah diperoleh karena memiliki kemampuan untuk tetap menjaga kualitas telur selama proses penyimpanan pada suhu 
ruang.

\section{METODE PENELITIAN}

Penelitian ini dilakukan di Laboratorium Biologi Universitas PGRI Argopuro Jember yang dilakukan dengan menggunakan metode eksperimental (Hadi Pranoto, 2013) dengan rancangan sebagai berikut:

$\mathrm{P}_{0}=$ Tanpa perendaman telur (Kontrol Negatif)

$\mathrm{P}_{1}=$ Perendaman telur dalam waktu 1 jam (Ekstrak jamu biji sebesar 10\%)

$\mathrm{P}_{2}=$ Perendaman telur dalam waktu 12 jam (Ekstrak jamu biji sebesar 10\%)

$\mathrm{P}_{3}=$ Perendaman telur dalam waktu 24 jam (Ekstrak jamu biji sebesar 10\%)

\section{Proses Ekstraksi Daun Psidium guajava.}

Proses pembuatan ekstrak daun biji sebelumnya dilakukan dengan memilih daun yang memiliki karakteristik daun muda. Daun jambu biji dikeringkan terlebih dahulu selama 15 menit sebelum direbus. Konsentrasi yang digunakan yaitu konsentrasi $10 \%$. (10 gr daun jambu biji ditambah aguades hingga $100 \mathrm{ml}$ ). Tahap selanjutnya untuk memperoleh senyawa tanin dilakukan dengan cara merebus daun tersebut dengan waktu \pm 10 menit (Nugroho, 2008 dalam Sri et al., 2011). Setelah direbus, campuran daun jambu biji dan aquades, selanjutnya dilakukan penyaringan dan dilanjutkan dengan mendinginkan ekstrak tersebut agar ampas daun hilang (Cornelia, 2014).

\section{Proses Perendaman Telur dengan Ekstrak Daun Psidium guajava.}

Proses perendaman dimulai dengan membersihkan terlebih dahulu telur yang akan direndam, dengan tujuan untuk menghilangkan kotoran yang menempel. Selanjutnya telur dibiarkan mengering dan kemudian menimbangnya dengan menggunakan timbangan analitik. Telur kemudian diberi nomor atau ditulis beratnya sesuai dengan berat yang sudah ditimbang. Setelah diberi nomor, selanjutnya merendam telur tersebut dengan menggunakan larutan ekstrak yang telah disiapkan dengan berbagai perlakuan yaitu selama 1 jam, 12 jam dan 24 jam. Setelah telur sedang proses perendaman, dilakukan pengamatan pada telur tersebut. Setelah perlakuan selesai, selanjutnya telur diletakkan pada egg tray serta dikeringaninkan agar bahan penyamak kering dan menempel sempurna pada telur (Fibrianti et al., 2012).

\section{Tahap penyimpanan dan Pengamatan}

Telur yang telah mendapatkan perlakuan perendaman dibiarkan selama \pm 4 minggu, 
dengan pengamatan tinggi putih telurnya dilakukan setiap 1 minggu sekali. Pengamatan dilakukan pada minggu 1, 2, dan 4 setelah perendaman untuk mengetahui daya tahan telur setelah direndam. Pengamatan yang dilakukan berupa besar haugh unit (HU) dengan menggunakan rumus $100 \log \left(\mathrm{H}+7,75-1,7 \mathrm{~W}^{0,37}\right)$. Huruf $\mathrm{H}$ disini merupakan besarnya nilai albumen kental (dalam mm), sedangkan huruf $\mathrm{W}$ adalag besar berat telur (dalam gram). Putih telur yang diukur yaitu pada putih telur yang dekat dengan bagian yang cair (kulit telur). Hal ini karena pada bagian putih telur ini kental, sedangkan yang terletak didekat kuning telur itu bagian putih telur yang cair (Purdiyanto, 2018).

Analisis data menggunakan teknik RAL (Rancangan Acak Lengkap) dan dianalisis ragam (Anova), dan diuji lanjut dengan menggunakan uji Duncan.

\section{HASIL DAN PEMBAHASAN}

Dari data yang diperoleh, maka untuk hipotesis bahwa ekstrak daun jambu biji dapat mempengaruhi daya tahan telur. Data dianalisis menggunakan uji ANOVA atau uji $\mathrm{f}$ taraf $5 \%$ maka H1diterima tetapi jika sebaliknya maka H0 yang diterima (Tabel 1). Pada parameter haugh unit setelah data diperoleh dan diuji dengan ANOVA taraf 5\% diperoleh



Tabel 1. Hasil Analisis Uji Anova

\begin{tabular}{|l|r|r|r|r|r|}
\cline { 2 - 6 } \multicolumn{1}{l|}{ haugh unit } & & & & \multicolumn{1}{c|}{. } & \multicolumn{1}{c|}{ Sig. } \\
\hline & Sum of Squares & df & Mean Square & F & .003 \\
\hline Between Groups & 1809.093 & 3 & 603.031 & 5.191 & \\
Within Groups & 6505.314 & 56 & 116.166 & & \\
Total & 8314.407 & 59 & & & \\
\hline
\end{tabular}

Hasil penelitian ini meliputi pengamatan tentang kualitas telur dengan menggunakan nilai HU (Haugh Unit) (Buckleet al., 1986), yang data pengamatannya dapat diamati pada Tabel 2 .

Tabel 2. Pengaruh Perendaman terhadap Nilai Haugh Unit Telur Selama Penyimpanan

\begin{tabular}{cccccc}
\hline $\begin{array}{c}\text { Pengamatan pada } \\
\text { minggu ke }\end{array}$ & \multicolumn{4}{c}{ Perlakuan } & \multirow{2}{*}{ Rata rata } \\
\cline { 2 - 5 } & P0 & P1 & P2 & P3 & \\
\hline 1 & 79,998 & 86,434 & 83,242 & 81,5 & 82,7935 \\
\hline 2 & 65,612 & 82,376 & 72,42 & 71,816 & 73,306 \\
\hline 4 & 44,89 & 67,94 & 63,182 & 59,022 & 58,7585 \\
\hline
\end{tabular}

Hasil penelitian yang telah dilakukan yaitu telur yang disimpan pada satu minggu dengan lama perendaman 1, 12, dan 24 jam memiliki kualitas AA dengan rata- rata nilai 82,79. Dan untuk data penyimpanan telur dengan waktu selama 2 minggu dengan lama 
perendaman 1 jam dan perendaman 12 jam saja yang memiliki kualitas AA dengan rata rata nilai 77,39 dan yang 24 jam memiliki kualitas B dengan nilai 71,81. Sedangkan pada telur yang disimpan selam 4 minggu tidak ada yang berkualitas AA. Pada minggu 4 ini telur yang direndam selama 1 dan 12 jam hanya memiliki kualitas A dengan rata - rata nilai 65,56, sedangkan yang lainnya memiliki tingkat kualitas yaitu B. Berdasarkan hasil penelitian menujunkkan bahwa semakin lama penyimpanan maka kualitas telur juga akan mengalami penurunan.

Pada pengamatan perendaman dan penyimpanan telur di minggu I, menunjukkan bahwa nilau HU tidak terdapat perbedaan untuk semua perlakuan tetapi pada minggu ke II (perlakuan kontrol negatif) terlihat adanya perbedaan berupa perubahan kondisi telur dibandingkan dengan perlakuan perendaman 1, 12, dan 24 jam. Pada minggu ke-4 penurunan nilai HU pada kontrol negatif menunjukkan adanya perubahan dibandingkan perlakuan perendaman 1, 12, dan 24 jam.

Hal ini sesuai dengan penelitian yang telah dilakukan oleh Cornelia (2014), bahwa kandungan pada telur yang disimpan dalam waktu lama akan mengakibatkan perubahan kadar $\mathrm{CO}_{2}$ yang menyebabkan kadar $\mathrm{pH}$ pada telu menjadi basa. Selain itu, penelitian juga telah dilakukan oleh Akyurek dan Okur (2009) dalam Djaelani (2016), menunjukkan bahwa penyimpanan telur yang semakin lama akan membuat putih telur maupun kuning telur mengalami kenaikan yang diakibatkan oleh kenaikan $\mathrm{pH}$ telur. Perubahan $\mathrm{pH}$ ini disebabkan hilangnya kandungan $\mathrm{CO} 2$ melalui pori-pori kulit telur sehingga merusak sistem buffer telur yang membuat $\mathrm{pH}$ menjadi basa (Jazil et al., 2013).

Hasil penelitian ini mengacu pada standart kualitas yang telah ditetapkan bahwa telur yang memiliki nilai HU minimal 72 masuk kedalam kategori kualitas AA, nilai HU antara 60-72 masuk kedalam kategori kualitas A sedangkan telur yang memiliki nilai HU antara 31-60 maka masuk kedalam kategori C (Nesheim et al., 1974).

\section{SIMPULAN}

Pada penelitian ini, dapat diperoleh kesimpulan yaitu terdapat pengaruh kualitas telur dengan perendaman menggunakan ekstrak daun Psiduim guajava selama proses penyimpanan, di mana perendaman P1 (1 Jam) pada minggu ke I menunjukkan hasil yang lebih baik $(86,434)$ dibandingkan dengan perlakuan lainnya. 


\section{DAFTAR PUSTAKA}

Buckle, K.A., Ra.Edward, G.H.Fleet and M.Wooton. (1986). Ilmu Pangan. Diterjemahkan oleh H.Purnomo dan Adiono. U.LPress.Jakarta.

Cornelia, A., Suada, I. K., \& Rudyanto, M. D. (2014). Perbedaan Daya Simpan Telur Ayam Ras yang Dicelupkan dan Tanpa Dicelupkan Larutan Kulit Manggis. Indonesia Medicus Veterinus, 3(2), 112-119.

Darmawati, S., \& Nurullita, U. (2009). Perbedaan Variasi Lama Simpan Telur Ayam pada Penyimpanan Suhu Almari Es dengan Suhu Kamar terhadap Total Mikroba. Jurnal Kesehatan, 2(1).

Djaelani, M. A. (2016). Kualitas Telur Ayam Ras (Gallus L.) Setelah Penyimpanan yang Dilakukan Pencelupan pada Air Mendidih dan Air Kapur Sebelum Penyimpanan. Buletin Anatomi Dan Fisiologi dh Sellula, 24(1), 122-127.

Fibrianti, S. M., Suada, I. K., dan Rudyanto, M. D. (2012). Kualitas Telur Ayam Konsumsi yang Dibersihkan dan Tanpa dibersihkan Selama Penyimpanan Suhu Kamar. Indonesia Medicus Veterinus, 1(3), 408-416.

Haryoto. (2010). Membuat Telur Asin. Kanisius. Yogyakarta.

Jazil, N., Hintono, A., \& Mulyani, S. (2013). Penurunan Kualitas Telur Ayam Ras dengan Intensitas Warna Coklat Kerabang Berbeda Selama Penyimpanan. Jurnal Aplikasi Teknologi Pangan, 2(1).

Lestari, S., Ratmawati, M., \& Syamsudin, G. (2013). Pengawetan telur dengan perendaman ekstrak daun melinjo (Gnetum gnemon linn). J. Sains \& Teknologi, 13(2), 184-189.

Muchtadi, T. R., \& Ayustaningwarno, F. (2010). Ilmu Pengetahuan Bahan Pangan.

Nesheim, M.C, REAustic,LE.Card. (1974).Poultry Production- Twell.FthFd.Lea \& Febiger,Philadelphia.

Purdiyanto, J. (2018). Pengaruh Lama Simpan Telur Itik terhadap Penurunan Berat, Indeks Kuning Telur (Ikt), dan Haugh Unit (Hu). Maduranch.: Jurnal Ilmu Peternakan, 3(1), 23-28. 